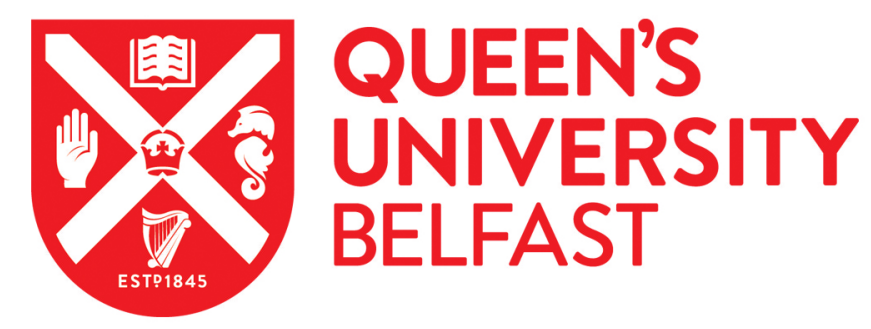

\title{
An Inconvenient Truth: Barriers to Truth Recovery in the Aftermath of Institutional Child Abuse in Ireland
}

McAlinden, A-M. (2013). An Inconvenient Truth: Barriers to Truth Recovery in the Aftermath of Institutional Child Abuse in Ireland. Legal Studies, 33(2), 189-214. https://doi.org/10.1111/j.1748-121X.2012.00243.x

\section{Published in:}

Legal Studies

Document Version:

Peer reviewed version

Queen's University Belfast - Research Portal:

Link to publication record in Queen's University Belfast Research Portal

\footnotetext{
General rights

Copyright for the publications made accessible via the Queen's University Belfast Research Portal is retained by the author(s) and / or other copyright owners and it is a condition of accessing these publications that users recognise and abide by the legal requirements associated with these rights.
}

Take down policy

The Research Portal is Queen's institutional repository that provides access to Queen's research output. Every effort has been made to ensure that content in the Research Portal does not infringe any person's rights, or applicable UK laws. If you discover content in the Research Portal that you believe breaches copyright or violates any law, please contact openaccess@qub.ac.uk. 


\title{
An inconvenient truth: barriers to truth recovery in the aftermath of institutional child abuse in Ireland
}

\author{
Anne-Marie McAlinden* \\ School of Law, Queen's University Belfast, Northern Ireland
}

Contemporary settled democracies, including the USA, England and Wales and Ireland, have witnessed a string of high-profile cases of institutional child abuse in both Church and State settings. Set against the broader literature on transitional justice, this analysis argues that there are significant barriers to truth recovery within the particular context of historical institutional abuse by the clergy in the Republic of Ireland. In the main, it argues that the frameworks of the inquiries and commissions into historical institutional child abuse are not conducive to truth recovery or the search for justice in dealing with the legacy of an abusive past. It is the Church-State relationship which makes the Irish situation noteworthy and unique. The Catholic Church and child care institutions are especially self-protective, secretive and closed by nature, and strongly discourage the drawing of attention to any deficiencies in organisational procedures. The nature of the public inquiry process also means that there is often a rather linear focus on accountability and apportioning blame. Collectively, such difficulties inhibit fuller systemic investigation of the veracity of what actually happened and, in turn, meaningful modification of child care policies. The paper concludes by offering some thoughts on the implications for transitional justice discourses more broadly as well as the residual issues for Ireland and other settled democracies in terms of moving on from the legacy of institutional child abuse.

\section{INTRODUCTION}

'[T]his is not Rome. Nor is it industrial school or Magdalene Ireland, where the swish of a soutane, smothered conscience and humanity and the swing of a thurible ruled the Irish Catholic world. This is the Republic of Ireland in 2011. It is a republic of laws, rights and responsibilities and proper civic order where the delinquency and arrogance of a particular version of a particular kind of morality will no longer be tolerated or ignored.' 1

Over the last few decades, stable Western democracies have experienced a number of high-profile cases of institutional child abuse within the context of both Church and State organisations. These have related to the physical or sexual abuse of children in

* I am grateful to my colleagues, Professors Kieran McEvoy and Shadd Maruna, and to the two anonymous reviewers for their insightful comments on earlier drafts of the paper. Any errors are, of course, my own.

1. E Kenny Dáil Debates Wednesday 20 July 2011, 1:00pm. 


\section{Legal Studies}

a wide range of professional settings. ${ }^{2}$ They include secular and religious, paid and voluntary work, ${ }^{3}$ within residential homes ${ }^{4}$ and schools, ${ }^{5}$ as well as community-based child care contexts such as nursery schools ${ }^{6}$ and foster placements. ${ }^{7}$ Institutional child abuse by the clergy - in particular members of Catholic religious orders - is something of a worldwide phenomenon and has impacted in an array of jurisdictions such as the USA, ${ }^{8}$ Canada, ${ }^{9}$ Australia, ${ }^{10}$ England and Wales, ${ }^{11}$ and, more recently, Germany, Belgium, Austria and Northern Ireland. ${ }^{12}$ The focus of this paper is predominantly on Ireland's experience of dealing with the legacy of an abusive past, although several other countries are referred to throughout for the purposes of comparison and illustration. The occurrence of these cases in the Republic of Ireland has been the most recent and prolific - generating sustained public and political furore and debate for more than a decade. Indeed, it is the relationship between Church and State in Ireland which makes the Irish situation particularly noteworthy and fairly unique. ${ }^{13}$

Other 'settled democracies' have also used transitional justice frameworks to deal with the legacy of institutional abuse. Australia and Canada, for example, have used a mixture of apology, reparation, compensation and truth commission as responses to clerical abuse as well as institutional abuses against indigenous peoples. ${ }^{14}$ Ireland, however, has primarily opted for a form of truth commission as means of examining historical institutional child abuse. In this context, there have been a number of inquiries into institutional child abuse in Ireland. These have included the Ferns

2. J Sullivan and A Beech 'Professional perpetrators' (2002) 11 Child Abuse Review 153.

3. DR Smith Safe from Harm: A Code of Practice for Safeguarding the Welfare of Children in Voluntary Organisations in England and Wales (London: Home Office, 1993).

4. B Corby, A Doig and V Roberts Public Inquiries into Abuse of Children in Residential Care (London: Jessica Kingsley, 2001).

5. C Brannan, R Jones and J Murch Castle Hill Report: Practice Guide (Shrewsbury: Shropshire County Council, 1993).

6. P Hunt Report of the Inquiry into Multiple Abuse in Nursery Classes in Newcastle Upon Tyne (Newcastle Upon Tyne: City Council, 1994).

7. K. Browne and MA Lynch 'The experiences of children in public care' (1999) 8 Child Abuse Review 353.

8. See K Terry et al (John Jay College Research Team) The Nature and Scope of the Problem of Sexual Abuse of Minors by Catholic Priests and Deacons in the United States, 1950-2002 (2004), available at http://www.usccb.org/nrb/johnjaystudy/index.htm.

9. See Law Commission of Canada Restoring Dignity: Responding to Child Abuse in Canadian Institutions (Ottawa: Law Commission of Canada, 2000).

10. L Forde The Commission of Inquiry into Abuse of Children in Queensland Institutions: Final Report (Brisbane: Government of Queensland, 1999).

11. See L Nolan Report of the Review on Child Protection in the Catholic Church in England and Wales: A Programme for Action (2001), available at http://www.cathcom.org/ mysharedaccounts/cumberlege/finalnolan1.htm ('The Nolan Report').

12. Note, however, that the phenomenon is not confined to the Catholic Church. See P Parkinson, K Oats and A Jayakody A Study of Reported Sexual Abuse in the Anglican Church (2009), available at http://www.apo.org.au/research/study-reported-child-sexual-abuseanglican-church.

13. M Keenan " "Them and us": the clergy child sexual offender as "other" ' in T Flannery (ed) Responding to the Ryan Report (Dublin: Columba Press, 2009).

14. See C Brennan 'Facing what cannot be changed: the Irish experience of confronting institutional child abuse' (2007) 29 Journal of Social Welfare and Family Law 245; J Llewellyn 'Dealing with the legacy of native residential school abuse in Canada: litigation, ADR and restorative justice' (2002) 52 University of Toronto Law Journal 253. 
Report, ${ }^{15}$ the Ryan Report, ${ }^{16}$ the Murphy Report ${ }^{17}$ and, most recently, the Cloyne Report. ${ }^{18}$ I argue, however, that the particular architecture of these inquiries is not conducive to 'truth recovery' or to the search for justice in the public accounting of the past. Indeed, while there has also been newspaper commentary,${ }^{19}$ television documentaries,$^{20}$ biographical accounts by survivors of clerical abuse ${ }^{21}$ and a few historical analyses which have emerged over the last few years, ${ }^{22}$ the issue has not yet been subjected to rigorous and sustained legal analysis. This paper is, therefore, aimed at filling this specific gap in the literature.

As the opening quotation by the Taoiseach makes clear, this is a seminal, transitional moment in Irish legal history which will have potential social and political consequences for Ireland and, in particular, its historical and deeply enmeshed relationship with the Catholic Church. As will be discussed further below, the political privilege afforded to Catholicism within the Irish State and in turn within the national imagination ultimately gave the Church enormous power and influence over the lawand policy-making processes in a diverse range of areas of Irish life. The ambiguous landscape and extra-legal dimension of the Church-State relationship in law within Ireland, however, had clear consequences for the policing of deviance, particularly where wrongdoing on the part of the Church was alleged to have occurred. The paper, in this respect, critically examines barriers to 'truth recovery' and failures to learn from past transgressions within the context of institutional child abuse as well as the likely implications for future Church-State relations in Ireland in the aftermath of the Cloyne Report.

This paper draws on the theoretical framework of 'transitional justice' - in particular the literature on 'truth recovery' - to advance its core argument that there are considerable obstacles to eliciting the truth in the aftermath of inquiries into historical institutional child abuse by the clergy in Ireland. While this framework is typically applied in the aftermath of political conflicts and human rights abuses, the "mainstreaming' or 'normalisation' of 'the language and tools of transitional justice' is also evident, as noted above, in its use as a response to institutional child abuse where such discourses have also been used as a means of transitioning from previous authoritarian

15. FD Murphy, H Buckley and L Joyce The Ferns Report, Presented by the Ferns Inquiry to the Minister for Health and Children (Dublin: Government Publications, 2005) ('The Ferns Report').

16. Report of the Commission to Inquire into Child Abuse (Chair: Judge Séan Ryan) (2009), available at http://www.childabusecommission.ie/ ('The Ryan Report').

17. Commission of Investigation, Report into the Catholic Archdiocese of Dublin (Chair: Judge Yvonne Murphy) (Dublin: Department of Justice and Law Reform, 2009) ('The Murphy Report').

18. Commission of Investigation, Report into the Catholic Diocese of Cloyne (Chair: Judge Yvonne Murphy) (Dublin: Department of Justice and Law Reform, 2011) ('The Cloyne Report').

19. See, especially, J Waters 'Child abuse continues in different guises', The Irish Times, 22 May 2009; F O'Toole 'Law of anarchy, cruelty of care', The Irish Times, 23 May 2009; F O'Toole, 'Lessons in the power of the Church', The Irish Times, 6 June 2009.

20. See, eg, Dear Daughter (1996); States of Fear (1999); Suing the Pope (2002).

21. See, eg, P Doyle The God Squad (London: Corgi Books, 1989); C O'Gorman, Beyond Belief (London: Hodder \& Stoughton, 2009).

22. See, eg, M Raftery and E O'Sullivan Suffer the Little Children: The Inside Story of Ireland's Industrial Schools (Dublin: New Island, 1999); B Arnold The Irish Gulag: How the State Betrayed its Innocent Children (Dublin: Gill \& Macmillan, 2009). 
regimes. ${ }^{23}$ In this respect, the paper also makes a contribution to the literature on transitional justice more generally by extending such discourses into the specific field of institutional child abuse in Ireland in light of the historical relationship between the Irish State and the Catholic Church as an autocratic State-like entity.

In brief, the process of 'truth seeking' - examining historical abuse, often exposing details and accounts previously hidden or 'covered up' by the authorities, in order to make the transition from one order or era to another - requires the full collaboration and disclosure by relevant stakeholders - individuals, organisations as well as government. I will argue, however, that denial and minimisation by both Church and State factions in the wake of allegations of institutional child abuse mean that there is often a rather linear focus on accountability and apportioning blame for acts or omissions. Such innate difficulties inhibit fuller systemic investigation of the veracity of what actually happened and, in turn, meaningful modification of child care practices and procedures.

The analysis will explore two interrelated lines of argument which are differentiated and unpacked here for the purposes of critical discussion. These factors may help to explain not only impediments to uncovering the truth when allegations eventually come to light, but also why such abuse is allowed to remain hidden and undisclosed in the first instance. First, I explore the highly complex and multi-layered ChurchState relationship in the Republic of Ireland. This analysis gives rise to consideration of a number of variables such as the historical power and position of the Catholic Church in Ireland; the fact that many institutions, such as industrial schools, were run by religious orders on behalf of and as a de facto adjunct of the State; and the political and social deference to Catholicism which collectively meant that the actions of the Church were largely beyond reproach. The combination of these factors meant that the State at times did not take action immediately in investigating complaints or tried to ignore or deflect allegations of abuse when they did come to light. Indeed, this interplay between Church and State also gives the latter a vested interest in selfpreservation when called to account.

In the second line of argument I will draw on the work of Cohen ${ }^{24}$ and Anderson, ${ }^{25}$ respectively, in relation to the tendency for Church and State 'communities' to deny or minimise wrongdoing, and the stark contrast between their 'imagined selves' and the legacy of an abusive past. There are usually two oppositional responses of the State when called to account: a focus on retribution as demonstrable evidence of its strength and commitment to controlling the problem, ${ }^{26}$ and a politics of denial of responsibility. ${ }^{27}$ England and Wales, for example, have largely opted for the former following disclosures of institutional child abuse.$^{28}$ In the Republic of Ireland, however, I argue that the State's historic response to the regulation of sexual crime in general, and to institutional child abuse in particular, is more clearly related to the

23. See K McEvoy and L Mallinder Knowledge Construction and the Mainstreaming of Transitional Justice: Truth, Memory and Dealing with the Past in 'Settled Democracies' International Studies Association Annual Convention (New Orleans, LA, 2010).

24. S Cohen States of Denial: Knowing About Atrocities and Suffering (Cambridge: Polity Press, 2001).

25. B Anderson Imagined Communities (London: Verso, 1983).

26. D Garland 'The limits of the sovereign state: strategies of crime control in contemporary society' (1996) 36 British Journal of Criminology 445.

27. Cohen, above n 24.

28. A McAlinden 'Vetting sexual offenders: state over-extension, the punishment deficit and the failure to manage risk' (2010) Social and Legal Studies 25. 
latter. The power of the Catholic Church and the traditionally high degree of trust and respect placed by Irish society in its clergy are also examined here in terms of a wider process of cultural and social denial about the existence of institutional child abuse in Ireland.

The structure of the paper will be as follows. The first part will provide an overview of public and official inquiries into institutional child abuse in the Republic of Ireland. A brief comparison is made with England and Wales where a number of high-profile cases of institutional abuse have resulted in a range of new policies and legislation in the area of pre-employment vetting. The second part will outline the key themes emerging from the literature on transitional justice and truth recovery processes which are critical to the present discussion. This includes the centrality of legal frameworks to transitional justice contexts and the problems generated by elitist agendas therein. The third and main part of the paper will critically examine the variety of impediments to truth recovery in the particular context of the aftermath of institutional child abuse by the clergy in Ireland. These relate to the multifarious Church-State relationship, and denial and minimisation by Church and State as well as civil society. Finally, the paper will conclude by offering some thoughts on how Ireland and other contemporary settled democracies may ensure genuine truth recovery and transition in the aftermath of historical institutional child abuse inquiries and ultimately meaningful modification of child care practices.

\section{INSTITUTIONAL CHILD ABUSE IN IRELAND: INQUIRIES AND REVIEWS}

Historically, State inquiries into the care of children in Ireland can be divided into three periods. The 1930s-1970s saw the publication of the Cussen ${ }^{29}$ and the Kennedy ${ }^{30}$ reports, which were highly critical of the widespread use of institutional care for children in Ireland, the lack of State commitment to the provision of basic child care services and, in particular, the excessive use of corporal punishment. From the 1970s to the late 1990s there were a series of inquiries into abuse within intra-familial contexts (eg, the Kilkenny Incest Inquiry ${ }^{31}$ and the McColgan case) ${ }^{32}$ These highlighted weaknesses in information sharing between agencies and the general unwillingness of the State to intervene in cases of suspected sexual abuse because of an emphasis on maintaining the family unit and professional incredulity of sexual abuse. From the late 1990s onwards, a number of cases highlighted the vulnerability of children in environments traditionally considered safe such as orphanages, clubs and schools. ${ }^{33}$ Within this broader context, the sexual and

29. Report of the Commission of Inquiry into the Reformatory and Industrial School System, 1934-1936 (London: The Stationery Office, 1936) ('The Cussen Report').

30. Reformatory and Industrial Schools System Report (London: The Stationery Office, 1970) ('The Kennedy Report').

31. $\mathrm{C}$ McGuinness The Report of the Kilkenny Incest Investigation (London: The Stationery Office, 1993).

32. North Western Health Board Report of the Inquiry into the West of Ireland Farmer Case (Manorhamilton: North Western Health Board, 1998).

33. A McAlinden " "Setting "em up": personal, social and institutional grooming in the sexual abuse of children' (2006) 15 Social and Legal Studies 339 at 350. See also R Murphy Report of the Independent Inquiry into Matters Relating to Child Sexual Abuse in Swimming (Dublin: Department for Tourism, Sport and Recreation, 1998). 


\section{Legal Studies}

physical abuse of children by members of Catholic religious orders has become the predominant contemporary concern. As a result of a number of high-profile cases of clerical sexual abuse, the stereotypical image of the 'paedophile priest' was generated and endorsed by the media internationally by the early $1990 \mathrm{~s}^{34}$ The key components of this construction were the use of religious vernacular which emphasised the nature of the crisis as pertaining not just to the individual offender, but to the institutional Church. ${ }^{35}$

The issue first came to public attention in Ireland with the highly publicised Fr Brendan Smyth case, following a television documentary. ${ }^{36}$ Smyth was sentenced to 12 years in prison after pleading guilty to 74 charges of indecent and sexual assault, involving the sexual abuse of 20 young people over a period of 36 years. He had previously served four years in a Northern Ireland prison for similar offences. His case achieved notoriety also because the then Taoiseach, Albert Reynolds, was forced to resign after revelations that the Attorney-General delayed processing requests for Smyth's extradition. The fact that this resignation took place at a key juncture in the emerging peace process in which Reynolds was a central player speaks directly to the importance of the intricate relationship between the Church and the State in Ireland and, in particular, the historical indemnity afforded to the Catholic Church by the Irish State not in law, but in practice.

The case was immediately followed by a string of allegations of child abuse involving members of religious orders. ${ }^{37} \mathrm{~A}$ series of television documentaries ${ }^{38}$ and accounts of clerical abuse by journalists ${ }^{39}$ and adult survivors of abuse ${ }^{40}$ highlighted the widespread abuse of children in institutions run by religious orders on behalf of the State and the Catholic hierarchy's poor handling of abuse complaints. These groups were instrumental in 'breaking the silence' and in making the issue a legitimate one for public debate. The then Taoiseach, Bertie Ahern, issued the first public political apology to victims of institutional child abuse on behalf of the Irish State in May 1999. The Commission to Inquire into Child Abuse was established to investigate complaints and hear the personal testimonies of those who had been abused. ${ }^{41}$ The Residential Institutions Redress Board was also set up as a compensation scheme for victims of institutional abuse. ${ }^{42}$ In the controversial Congregational Indemnity Agreement concluded in 2002, the State indemnified the congregations against any subsequent legal action by abuse victims in consideration for a relatively small contribution

34. See, especially, H Ferguson 'The paedophile priest: a deconstruction' (1995) 84 Studies 247; P Jenkins Paedophiles and Priests: Anatomy of a Contemporary Crisis (Oxford: Oxford University Press, 1996).

35. Such religious terminology is also reflected in the titles of earlier American books on the subject, eg, J Berry Lead Us Not Into Temptation: Catholic Priests and the Sexual Abuse of Children (New York: Doubleday, 1992); S Rosetti (ed) Slayer of the Soul: Child Sexual Abuse and the Catholic Church (New London, CT: Twenty-third Publications, 1990).

36. Suffer Little Children (1994). See C Moore Betrayal of Trust: The Father Brendan Symth Affair and the Catholic Church (Dublin: Marino, 1995).

37. R Sipe 'Priest sex abuse case stirs political storm in Ireland', National Catholic Reporter, 2 December 1994.

38. See, especially, States of Fear, above n 20.

39. Above $\mathrm{n} 19$.

40. Above $n 21$.

41. See Commission to Inquire into Child Abuse Act 2000, and Commission to Inquire into Child Abuse (Amendment) Act 2005.

42. See Residential Institutions Redress Act 2002. 
to the overall costs of the redress scheme. ${ }^{43}$ The issue, however, exploded in terms of public controversy and private litigation following publication of a series of historical inquiry reports in quick succession.

The first of these, the Ferns Report, ${ }^{44}$ was published in October 2005. It investigated the handling of over 100 allegations of child sexual abuse against 21 priests in the diocese between 1966 and 2002. The Report highlighted the failure of the Church, and bishops in particular, to respond to complaints of abuse, chiefly by non-removal of priests from active ministry and the non-reporting of complaints to the civil authorities. It also underlined the subsequent failures of State agencies, including the Gardaí and the health authorities, to investigate effectively and prevent the further abuse of victims.

Over the course of nine years, the Commission to Inquire into Child Abuse investigated the treatment of children in residential institutions run by Catholic religious orders, dating back to 1936. The publication of the Commission's five-volume Report ${ }^{45}$ in May 2009 generated widespread media coverage and public outcry throughout Ireland and beyond. ${ }^{46}$ The Report was highly significant because it highlighted the fact that the abuse of children (physically, sexually, emotionally and through neglect), and the failure of Church and State authorities to adequately respond to the problem, was systemic in Irish child care institutions. ${ }^{47}$

The Report of the Commission of Investigation into the Catholic Archdiocese of Dublin $^{48}$ was published a few months later in November 2009. It examined the handling of complaints of child sexual abuse by Church and State authorities in the Archdiocese from 1975 to 2004. The Report concluded that clerical child sexual abuse was 'covered-up' during this period. ${ }^{49}$ Successive Archbishops and bishops failed to report their concerns to the Gardaí, ${ }^{50}$ and often the suspected perpetrator was transferred to another parish or diocese where they continued to have access to minors and the opportunity to abuse again. Further, there were inappropriate communications between Church and State authorities in relation to the handling of abuse allegations. ${ }^{51}$

The Commission's Report into the Catholic Archdiocese of Cloyne ${ }^{52}$ was published in July 2011. It examined the handling of allegations and concerns about child sexual abuse during the period 1 January 1996-1 February 2009. The historical remit is significant because it covers the period in which the Catholic Church in Ireland first put in place procedures to deal with allegations of abuse and is two years after the Smyth case first came to light. The Report concluded that the response of the Church was 'inadequate and inappropriate ${ }^{53}$ and that it had failed, inter alia, to carry out proper canonical investigations; to report all complaints to the Gardaí or health authorities; and to implement an independent advisory panel which could assist

43. Arnold, above n 22, pp 122-127.

44. Ferns Report, above n 15.

45. Ryan Report, above $\mathrm{n} 16$.

46. S Fagan 'The abuse and our bad theology' in T Flannery (ed) Responding to the Ryan Report (Dublin: Columba Press, 2009) p 14.

47. Ryan Report, above n 16, vol IV, paras 6.09-6.18.

48. Murphy Report, above n 17, established under the Commissions of Investigation Act 2004.

49. Ibid, para 1.113 .

50. Ibid, paras $1.32-1.36$.

51. Ibid, paras $1.92-1.96,1.101$.

52. Cloyne Report, above n 18.

53. Ibid, para 1.71 . 


\section{Legal Studies}

Church authorities in taking appropriate action when an allegation of abuse was made. Survivors of the 'Magdalene laundries' (institutions run by religious orders which housed unmarried mothers and 'fallen women') are also campaigning for an inquiry into the practices of those institutions. ${ }^{54}$

In common with the literature on institutional child abuse in England and Wales, ${ }^{55}$ a number of recurring themes emerge from these inquiries: many complaints were not formally reported; the abuse normally took place over a number of years and its extent went unrecognised for some time; and the victims were afraid to disclose the abuse, or when they did no action was taken by the authorities, either because there was a conspiracy to keep allegations quiet or a ready acceptance of the denial by the alleged perpetrator. ${ }^{56}$ Some of these issues, including delays in disclosure, the "conspiracy of silence' and denial and minimisation of allegations are of particular relevance to truth recovery and will be examined more fully below.

The Ferns Inquiry ${ }^{57}$ and the Ryan Commission ${ }^{58}$ made a number of recommendations in relation to improving institutional policies and the provision and management of services for children in care. Although a number of initiatives have been put in place by the Irish government, including reform of social services provision for children, the revelations in the Cloyne Report highlight the fact that the lessons of the past had not been learnt in the interim. ${ }^{59}$ Indeed, as will be discussed further below, it is only now in the immediate aftermath of the Cloyne Report that the proposals for wide-ranging reforms seem likely to come to fruition. These relate to the publication of the Criminal Justice (Withholding Information on Crimes against Children and Vulnerable Adults) Bill 2011 which will make it an offence to withhold such information, and the draft heads of the National Vetting Bureau Bill 2011 which will allow for exchange of 'soft information' on abusers.

Following the Ryan Report, the Vatican announced that it was to begin an investigation into the Irish Church's handling of suspected cases of sexual abuse. The 'apology' by Pope Benedict XVI to victims of clerical abuse in Ireland, however, was heavily criticised in that 'it did not go far enough' ${ }^{60}$ Victim spokespersons were dismayed in particular at the failure of the Vatican to admit its role in covering up repeated allegations of abuse. ${ }^{61}$ Indeed, it could reasonably be asserted that the public anger concerning the scandal is as much, if not more, about the cover-ups and other

54. See, eg, Justice for Magdalenes, the survivor advocacy group (http://www. magdalenelaundries.com, last accessed, 9 January 2012). See also the Interim Progress Report of the Inter-departmental Committee into Magdalene Laundries, set up to establish the facts of state involvement with these institutions, available at http://www.justice.ie/en/JELR/ MagdelanInterimReport2011Oct.pdf/Files/MagdelanInterimReport2011Oct.pdf

55. See, eg, B Gallagher Grappling with Smoke: Investigating and Managing Organised Abuse - A Good Practice Guide (London, NSPCC, 1998); C Barter 'Practitioners' experiences and perceptions of investigating allegations of institutional abuse' (1999) 4 Child Abuse Review 392. 56. See, generally, Berry, above $n 35$. Note, however, that clergy sexual abusers are not a homogeneous group. See, eg, CC Mercado, JA Tallon and KJ Terry 'Persistent sexual abusers in the Catholic Church: an examination of characteristics and offense patterns' (2008) 35 Criminal Justice and Behaviour 629.

57. Ferns Report, above $\mathrm{n} 15$, ch 8 .

58. Ryan Report, above $\mathrm{n} 16$, vol IV, ch 7 .

59. Cloyne Report, above $n 18$.

60. 'Abuse victim responds to Pope's apology', BBC News Online, 18 September 2010, available at http://www.bbc.co.uk/news/uk-northern-ireland-11357165.

61. Ibid. 
alleged shortcomings in the handling of abuses cases by secular and ecclesiastical authorities in particular as it was about the scale of the abuse itself.

In England and Wales, the disclosure of institutional physical and sexual abuse in State care homes also resulted in a series of public inquiries and reviews. ${ }^{62}$ These inquiries have made similar recommendations to improve pre-employment vetting which have not always been followed through.$^{63}$ Nonetheless, many of their recommendations were readily translated into policy and legislative reforms. The cases which have occurred in England and Wales, however, were more concerned with individual wrongdoing against the backdrop of an organisational environment than with the systemic nature of institutional abuse and the State's past failure to intervene. ${ }^{64}$ Within such a context, it becomes easier for the State to remove itself from any possible accusations of wrongdoing particularly where it demonstrates immediate political expediency and willingness to put in place corrective mechanisms to ensure such failures do not happen again.

Most recently, for example, the Safeguarding Vulnerable Groups Act 2006 was enacted to give legislative effect to many of the recommendations of the Bichard Inquiry. ${ }^{65}$ Although, this expansive framework is to be scaled back to 'common sense levels', ${ }^{66}$ the legislation establishes a centralised online register and continuous criminal records monitoring of every person who works or volunteers with children or vulnerable adults. ${ }^{67}$ By contrast, however, to date, the Republic of Ireland has not pursued a reformative, regulatory agenda in the aftermath of the inquiry reports with the same vigour. Possible explanations for these differences, and in particular the barriers to transition within the context of institutional child sexual abuse in Ireland, will be undertaken further below.

\section{JUSTICE IN TRANSITION: THE SEARCH FOR 'TRUTH'}

The process and outcomes of the recent inquiries and commissions which have investigated historical institutional child sexual abuse in Ireland can be usefully examined within a transitional justice framework, and in particular the search for the truth about the past. Transitional justice processes generally involve a range of models which are aimed at helping a society come to terms with previous large-scale human rights abuses in order to ensure accountability for wrongdoing, and achieve justice and reconciliation for victims. ${ }^{68}$ These may include judicial or extra-judicial mechanisms

62. See, in particular, Nolan Report, above n 11; Cumberlege Commission Safeguarding with Confidence: Keeping Children and Vulnerable Adults Safe in the Catholic Church (2007), available at http://www.cathcom.org/mysharedaccounts/cumberlege/report/index.asp. For an overview see, P Reder, S Duncan and, M Gray Beyond Blame: Child Abuse Tragedies Revisited (London: Routledge, 1993). See also Corby et al, above $\mathrm{n} 4$.

63. See, especially, N Parton 'From Maria Colwell to Victoria Climbié: reflections on public inquiries into child abuse a generation apart' (2004) 13 Child Abuse Review 80.

64. McAlinden, above $n 33$.

65. The inquiry was established following the conviction of school caretaker, Ian Huntley, for the murders of Holly Wells and Jessica Chapman in Soham in 2002. Sir M Bichard, The Bichard Inquiry Report (London: The Stationery Office, 2004).

66. See the Protection of Freedoms Bill 2010-2011. See also 'Nick Clegg reveals end of vetting scheme', The Independent, 11 February 2011.

67. McAlinden, above $\mathrm{n} 28$.

68. See, eg, R Teitel Transitional Justice (Oxford: Oxford University Press, 2000); K McEvoy 
such as prosecution, truth commissions, apology, reparation and, ultimately, institutional reform.

Within this context, 'truth recovery' in particular has emerged as a vital element of dealing with the legacy of the past. ${ }^{69}$ Fundamentally, truth recovery, often via the conduit of truth commissions, entails investigating patterns of abuse or crimes of past regimes, usually uncovering information previously concealed by the authorities, in order to make the transition from one order or era to another. The appeal of the truth recovery process lies in moving from 'the grip of a conflicted or authoritarian past ${ }^{\prime} 70$ and usually seeks to go beyond establishing the 'forensic truth' of what actually happened to a fuller institutional and structural understanding of the causes, context and consequences of past abuses. ${ }^{71}$

A detailed examination of the meaning of 'truth' is beyond the scope of this paper. It must be acknowledged at this juncture, however, that the notion of 'truth' itself is not a singular universally understood concept, but rather may be the subject of multiple meanings encompassing, for example, both subjective and objective, and individual, institutional as well as societal elements. ${ }^{72}$ As Campbell and Turner have suggested in the context of the political transition in Northern Ireland: there is "contemporary skepticism about the viability of meta-narratives (the one truth), and indeed of the viability of the notion of "objective" truth of any sort. ${ }^{73}$ In this regard, as will be discussed further below, part of the underlying problem it seems stems from the fact that the inquiries tried to use individual truth narratives pertaining to particular survivors of abuse in order to map an over-arching account of institutional abuse as a whole. The framework of truth recovery has traditionally been applied in the aftermath of violent political conflicts and serious human rights abuses such as those in Uganda, South Africa, Latin America and Northern Ireland. ${ }^{74}$ This section of the paper utilises the prism of truth recovery to examine the inherent limitations of such investigatory processes in the aftermath of institutional child abuse by the clergy in the Republic of Ireland.

There are, in general, recognised limitations of the truth-telling process in the aftermath of war and conflict. ${ }^{75}$ Medeloff, for example, argues that the core theoretical assumptions of truth-telling in dealing with the past - that it promotes

and L McGregor (eds) Transitional Justice from Below: Grassroots Activism and the Struggle for Change (Oxford: Hart, 2008).

69. See, generally, M Flournay and M Pan, 'Dealing with demons: justice and reconciliation' (2002) 25 Washington University Law Quarterly 111.

70. C Campbell and C Turner 'Utopia and the doubters: truth, transition and the law' (2008) 28 Legal Studies 374 at 374.

71. K. McEvoy Making Peace with the Past: Options for Truth Recovery in Northern Ireland (Belfast: Healing Through Remembering, 2006).

72. See, eg, S Cohen 'State crimes of previous regimes: knowledge, accountability and the policing of the past' (1995) 20 Law and Social Inquiry 7; AR Chapman and P Ball 'The truth of truth commissions: comparative lessons from Haiti, South Africa and Guatemala' (2001) 23 Human Rights Quarterly 1; J Tepperman 'Truth and consequences' (2002) (March/April) Foreign Affairs 128;

73. Campbell and Turner, above $n 70$, at 375.

74. See, eg, M Popkin and N Roht-Arriaza 'Truth as justice: investigatory commissions in Latin America' (1995) 20 Law and Social Inquiry 79; K McEvoy and H Conway 'The dead, the law and the politics of the past' (2004) 31 Journal of Law and Society 539.

75. See, generally, P Hayner Unspeakable Truths: Facing the Challenge of Truth Commissions (London: Routledge, 2002); M Freeman Truth Commissions and Procedural Fairness (Cambridge: Cambridge University Press, 2006). 
justice, fosters healing and reconciliation, allows for the establishment of an official record, facilitates public education, aids institutional reform, and pre-empts and deters future crimes - are highly contentious and largely empirically unproven. ${ }^{76}$ As will be discussed further below, in the context of the inquiry process into institutional child abuse in Ireland it seems that the aspirations in particular of providing an authoritative record of events and holding the perpetrators to account have not been realised. Within this broader critical context, others have underlined the importance of the normative framework of truth commissions or inquiries for eliciting the truth in either conceptual or legal terms. ${ }^{77}$

At the conceptual level, critical scholars have taken a cynical view of public inquiries arguing that official discourses within the process may be socially and politically constructed. ${ }^{78}$ In the search for accountability and truth there is often a rather restricted and limited focus on identifying and impugning the perpetrators and attributing fault for individual acts or omissions within the context of a particular crisis or scandal. The process of passing judgment and determining blame, which has also underpinned the inquiries into child abuse in England and Wales, ${ }^{79}$ obscures a meaningful and effective review of institutionalised policies and practices and misses the opportunity to learn from the past. In particular, a focus on the context and circumstances of abuse without also examining the latent consequences is incompatible with uncovering the 'full truth' of what occurred. Scraton, for instance, argues that the capacity of official inquiries 'for thoroughness in evidence gathering or disclosure, for establishing responsibility and securing acknowledgment and for challenging, institutional, structural determining contexts is questionable' ${ }^{80}$

In this respect, the terms of reference of two out of the four most recent inquiries (the Ferns and Murphy reports, respectively) were rather narrowly framed. The commissions were tasked with examining allegations and suspicions of abuse as reported to them and the responses to those allegations by the relevant authorities, rather than the truth of the allegations themselves and whether sexual abuse actually took place. In this context, only the Ryan Commission, with a fuller statutory mandate, could be deemed a 'truth' or historical investigatory commission in relative terms. At least in part, the investigatory process has, therefore, failed to establish who was responsible and provide a measure of accountability for the perpetrators.

At a broader level, the phenomenon of high-profile 'tribunals' of inquiry has grown in number and significance in Ireland since the early 1990s. These include those relating to, inter alia, payments to politicians by Ben Dunne (the McCracken Tribunal, which subsequently became the Moriarty Tribunal), ${ }^{81}$ complaints concerning some Gardaí in the Donegal Division (the Morris Tribunal), ${ }^{82}$ certain planning

76. D Medeloff 'Truth seeking, truth telling and post-conflict peace building: curbing the enthusiasm' (2004) 6 International Studies Review 355.

77. See, eg, L Huyse 'Justice after transition: on the choices successor elites make in dealing with the past' (1995) Law and Social Inquiry 51.

78. See, eg, P Scraton 'From deceit to disclosure: the politics of official inquiries in the United Kingdom' in G Gilligan and J Pratt (eds) Crime, Truth and Justice: Official Inquiry, Discourse, Knowledge (Cullompton: Willan, 2004).

79. Reder et al, above n 62, p 1.

80. Scraton, above $\mathrm{n} 78, \mathrm{p} 50$.

81. Report of the Tribunal of Inquiry into Payments to Politicians and Related Matters (2011), available at http://www.moriarty-tribunal.ie ('The Moriarty Tribunal').

82. Report of the Tribunal of Inquiry into Complaints concerning Some Gardai of the Donegal Division (2002-2008), available at http://www.morristribunal.ie ('The Morris Tribunal'). 
matters and payments (the Mahan Tribunal ${ }^{83}$ and the investigation of the Dublin and Monahan bombings of $1974,{ }^{84}$ as well as institutional child abuse. I would argue, however, that there are inherent limitations of the statutory tool of public inquiries in adopting an advisory and reform function - as judicially chaired and necessarily apolitical bodies, sometimes comprised of non-expert members - which have been little considered.

In particular, tribunals of inquiry typically operate on an ad hoc basis within a specific remit and terms of reference and are institutionally independent from the executive and legislative branches with the power to make recommendations. ${ }^{85} \mathrm{Such}$ constitutional constraints may limit not only their legitimacy to function as a democratic reform process, but also their capacity to ascertain a fuller or forensic truth. In this vein, the structure and form of the prevailing modes of inquiry in Ireland which are dictated by the requirements of constitutional justice are perhaps construed towards a narrow construction of 'truth' and are unsuitable by their very nature for the deeper systemic investigation that would lead to institutional reform. In short, the structural and administrative limits of truth recovery processes in Ireland might have deep-seated and more intractable roots than has previously been acknowledged.

In relation to the normative legal framework, the rule of law has been a central aspect of transitional contexts and has been used to confront the abuses of past regimes via an array of legal mechanisms such as truth commissions and inquiries. ${ }^{86}$ The hegemony of legalism in transitional justice discourses more broadly, ${ }^{87}$ and in truthseeking mechanisms specifically, ${ }^{88}$ has also been the subject of sustained critique. As Teitel has contended, the operation of law in transitional contexts is highly paradoxical partly because legal institutions and rules may have directly bolstered the previous authoritarian regime through, for example, overseeing a culture of impunity for human rights abusers. ${ }^{89}$ Indeed, the Ryan Commission has also been criticised from this standpoint - in particular its failure to underline the nature and extent of State involvement in abusive regimes and the limitations of its framework in uncovering the full truth about the past. ${ }^{90}$ This scepticism about the functionality and limitations of the formal legal rubric to "police the past" ${ }^{\text {'1 }}$ gives rises to two particular lines of critique.

83. Report of the Tribunal of Inquiry into Certain Planning Matters and Payments, available at http://www.flood-tribunal.ie/asp/Reports.asp?objectid=310\&Mode=0\&RecordID=504 ('The Mahan Tribunal').

84. Report of the Commission of Investigation into the Dublin and Monahan Bombings 1974: Final Report, March 2007, available at http://www.taoiseach.gov.ie/eng/Department_of_ the_Taoiseach/Policy_Sections/Northern_Ireland/Northern_Ireland_Publications.

85. See, generally, G Hogan and DG Morgan Administrative Law in Ireland (Dublin: Round Hall Press, 4th edn, 2010).

86. See G O'Donnell 'Why the rule of law matters' (2004) 15 Journal of Democracy 32; F Ní Aolaín and C Campbell 'The paradox of transition in conflicted democracies' (2005) 27 Human Rights Quarterly 172 at 187.

87. See, especially, K McEvoy 'Beyond legalism: towards a thicker understanding of transitional justice' (2007) 34 Journal of Law and Society 411.

88. Campbell and Turner, above $\mathrm{n} 70$.

89. Teitel, above $\mathrm{n} 68, \mathrm{p} 6$.

90. Arnold, above n 22, pp 249-256.

91. Cohen, above n 72 . 
The first of these is the criticism that 'law "sees" only a limited range of wrongs' ${ }^{92}$ In relation to mass atrocities in particular, the question arises as to whether the legal inquiry process in focusing in depth on a limited number of exemplary cases can ever fully reflect the seriousness and extent of such abuses. Typically, for example, the Irish inquiries into institutional child abuse did not report on all allegations of abuse but only on the most serious using either representative sampling of allegations against individual priests (the Murphy Commission) or selecting those institutions where the number of complaints was above a certain threshold (the Ryan Commission). Although the Ryan Commission underlined the systemic nature of abuses and inadequate responses to the problem, the investigation of 'truth' at the micro-level of fact-finding masks the broader structural narrative and the complexities of the institutional and cultural factors that allowed for the ongoing abuse.

At the same time, the structural narrative which does emerge is undermined by the institutional framework of the inquiry process. In particular, the singular focus on the direct victims of institutional abuse also fails to acknowledge secondary and tertiary victims - namely the families of victims, as well as the Catholic laity and the wider community. ${ }^{93}$ Moreover, a statistical focus on only the most serious violations or abuses also obscures the broader context of patterns of abuse and systemic wrongdoing over time. ${ }^{94}$ In such a context, the social narrative which emerges from the inquiries does not provide an authoritative record of events. Instead, a shared, subjective truth emerges which either minimises or subjugates the accounts provided by other witnesses whose experiences lie outside the dominant paradigm. ${ }^{95}$ Furthermore, as McEvoy writes, 'a focus on individual responsibility fails to take proper account of the complex collective factors which contribute to violence'. ${ }^{96}$

There is also a discernible structural macro-level dimension to some of the conclusions of the inquiry reports, however, which have been reflective and increasingly critical rather than formal and descriptive in nature. As will be discussed further below, both the Murphy and the Ryan reports, for example, denoted variously a culture of 'secrecy' or 'silence' which existed within the institutional Church. More particularly, however, the Cloyne Report, as noted above, was quite far-reaching and damning in its conclusion that the Church failed to follow its own guidelines on the handling of abuse complaints. It is perhaps, therefore, the lack of tangible follow-up on the part of the State until fairly recently - at least in part, and certainly in the aftermath of the earlier inquiry reports - that has undermined the legitimacy of the inquiry process and ultimately failed to promote organisational accountability by missing the opportunity to become a catalyst for seismic and structural change.

Secondly, elites are unlikely to engage fully in the process of eliciting the truth where the ultimate outcome may be public indictment and prosecution. ${ }^{97}$ 'Truth recovery', in this respect, requires the full cooperation and attendant disclosure by all the relevant stakeholders - the Catholic Church, the Irish State as well as individual

92. Campbell and Turner, above $\mathrm{n} 70$, at 376 .

93. See M Breen 'The truth will set you free: reflections on the Church's handling of child sexual abuse' (2002) 53 The Furrow 414. See also Re Doyle in which one father challenged the state to regain custody of his children who had been placed in state care (decided in 1956, reported in [1989] ILRM 277).

94. Campbell and Turner, above $n$ 70, at 376.

95. Chapman and Ball, above $n 72$.

96. McEvoy, above $\mathrm{n} 87$, at 438 .

97. Campbell and Turner, above n 70 , at 378 . 
perpetrators and victims. The Ryan Commission, in particular, had a statutory power to require disclosure of documents and compel relevant persons to submit to questioning. The inquiry reports did acknowledge the cooperation of Church and State authorities, for the most part, during the conduct of the inquiry process. However, many abusers were either not named publicly but were dealt with anonymously following legal challenge in the High Court by religious orders ${ }^{98}$ (the Ryan Commission and the Cloyne Report) or were given pseudonyms to protect their real identities to preserve the fairness of future prosecutions (the Murphy Report). However, partial anonymity and the failure to publicly identify abusers as structuring principles of the inquiry processes may have ultimately undermined their capacity to deliver justice for victims, particularly in terms of official public recognition of wrongdoing and suffering.

Indeed, there is an enduring reluctance it seems on the part of the higher echelons of the Catholic Church, and the Vatican in particular, to admit the full extent of its historical knowledge of child abuse by clergy and its concomitant efforts to keep allegations of abuse quiet. Equally, there is a fundamental tension between the challenges presented in the face of institutional failings by both the Church and the State, as underlined by the inquiries, and the willingness of these entities to effect systemic change. As will be discussed further below, the Church and State in Ireland, and the enmeshed relationship between them, are elite bodies with 'ossified and rigid structures ${ }^{99}$ which makes them particularly resistant to transitional processes and institutional change.

\section{BARRIERS TO TRUTH RECOVERY IN IRELAND}

The historical legacy of institutional child abuse by the clergy in Ireland is firmly embedded, firstly and more broadly, in the intricate nature of the Church-State relationship. Secondly, and following on from this, barriers to truth recovery can also be specifically related to discourses on denial and minimisation of the nature and extent of abuse by both Church and State entities as well as wider society, and the self-preservation of their own identities. These factors may at once explain why patterns of abuse remained hidden for so long as well as the difficulties in uncovering the full 'truth' when allegations eventually come to light.

\section{(a) The Church-State relationship}

In the USA, the Supreme Court has generally established the legal separation of Church and State. ${ }^{100}$ In Ireland, however, the institutions of Church and State have had

98. See Michael Murray and David Gibson v the Commission to Inquire into Child Abuse the Minister for Education \& Science, Ireland \& the Attorney General, unreported, 17 October 2003, Abbott J. Following the resignation of Chairperson Justice Mary Laffoy in December 2003 and the appointment of Justice Séan Ryan as the new chairperson in June 2004 and his announcement that the Commission no longer intended to name anyone, the Christian Brothers dropped their legal actions against the Commission.

99. Ní Aolaín and Campbell, above n 86, at 200.

100. See Walz v Tax Commission, 397 US 664 (1970). See also JR Formicola 'The Vatican, the American bishops and the Church-State ramifications of clerical sexual abuse' (2004) 46 Journal of Church and State 479 at 498. 
a rather vague and flexible association. The close political and affective relationship was shrouded by a stance of formal legal neutrality towards religion and a semblance of partial constitutional secularism. ${ }^{101}$

The Catholic Church in Ireland for much of twentieth century was 'a formidable and powerful institution, virtually unchallengeable', ${ }^{102}$ with influential powers in a range of settings including education, healthcare and censorship. ${ }^{103}$ This deference to Catholicism was political, however, rather than constitutional, and was merely accommodated rather than being actively prescribed within the legal or constitutional framework for Church-State relations. ${ }^{104}$ The 1922 Constitution, for example, was entirely secular despite the robust Catholic ethos of the newly formed Irish Free State. ${ }^{105}$ Under the 1937 constitution of the modern State of Ireland, the Catholic Church was enshrined with a 'special position' in Irish society. ${ }^{106}$ This reference, however, had no particular legal significance ${ }^{107}$ and was in fact removed via the Fifth Amendment in 1972. Moreover, its deletion had no direct bearing on the power of the Church within Ireland. These and other significant constitutional restraints ${ }^{108}$ inhibited any formal authority or privileged status being invested in any Christian church, including the Catholic Church in particular. ${ }^{109}$

Indeed, several scholars have more recently highlighted the complex constitutional picture as regards Church and State in Ireland. Hogan ${ }^{110}$ and Keogh and MCarthy, ${ }^{111}$ for example, argue that the Catholic influence on the constitutional order has been routinely overstated, and that the Catholic elements and input in the drafting process were counterbalanced with democratic-secularist influences. In reality, however, there was a great gulf between the praxis and law of Church-State relations. ${ }^{112}$ In this respect, until very recently, the State and its citizens appeared to accept without serious question the immense power and the hierarchical authority of the Church in

101. For an historical overview, see, generally, JH Whyte Church and State in Modern Ireland, 1923-79 (Dublin: Gill \& Macmillan, 1984). I am grateful to an anonymous reviewer for Legal Studies for alerting me to this point/issue.

102. F Ryan 'A lingering shame' in T Flannery (ed) Responding to the Ryan Report (Dublin: Columba Press, 2009) p 149.

103. See, generally, D Ferriter The Transformation of Ireland, 1900-2000 (Dublin: Profile Books, 2005) ch 5.

104. I am grateful to an anonymous reviewer for Legal Studies for alerting me to this point/ issue.

105. Ibid.

106. See the former Article 44.1.2.

107. See, eg, Article 42 of the Constitution on education which 'acknowledges that the primary and natural educator of the child is the family' and makes no reference to the rights of churches as educators.

108. See, eg, the prohibition on religious discrimination in Article 44.2.3 and the prohibition on religious endowment in Article 44.2.2 of the Constitution. See also Campaign to Separate Church and State Ltd $v$ Minister for Education [1998] 3 IR 321, in which during a constitutional challenge to the State funding of school chaplains it was held that the Constitution prohibited any 'establishment' of religion.

109. I am grateful to an anonymous reviewer for Legal Studies for alerting me to this point/ issue.

110. G Hogan 'De Valera, the Constitution and the historians' (2005) 40 Irish Jurist 293.

111. D Keogh and A McCarthy The Making of the Irish Constitution (Dublin: Mercier Press, 2007).

112. I am grateful to an anonymous reviewer for Legal Studies for alerting me to this point/ issue. 
civil and intimate life. The State, for example, reversed plans to introduce health and social reforms, such as the infamous 'Mother and Child Scheme' in 1951, after staunch opposition from the Catholic Church. The Church opposed this scheme, which was to provide free maternity care for expectant mothers and health care for children, on the grounds of unwanted State interference in family life. ${ }^{113}$ This symbiosis of Church and State and the dominant stature of the Catholic Church within Irish society had a number of important consequences.

First, as Raftery and O'Sullivan point out, the system of child care in Ireland underwent a major setback with the formation of the Irish State. ${ }^{114}$ The 1908 Children Act provided for the committal of children to industrial schools and reformatories by the courts without review. The system has been described as an 'Irish Gulag' and was, in effect, a prison system for children. ${ }^{115}$ In comparison, Britain had introduced a number of reforms to this Act within a few years of its implementation and was gradually moving away from mass institutional care. ${ }^{116}$ In Ireland, however, there was a deliberate halt to any such progress. This has been attributed to the central ideology of De Valera's Ireland and the adoption of conservative social policies which were based on the aspiration of complete political separation from the United Kingdom, ${ }^{117}$ a rigid Catholic ethos of morality and the covetous guarding of its national identity against any pervasive outside influences. ${ }^{118}$

The industrial schools were staffed and run by Catholic religious orders on behalf of the State. The Church did not tolerate interference from the State and with such a vested interest, not least in terms of financial and political support, neither was it to the State's benefit to challenge the authority of the Church or the practices within these institutions. ${ }^{119}$ There were occasional inspections by the Department of Education, but even where incidents came to light, ultimately no action was taken. ${ }^{120}$ As will be discussed further below, the State knew of the existence of the abuses of power and the severe mistreatment of children within its institutions but failed to intervene.

Secondly, establishing the power of the Catholic Church as the mainstay of Irish life also gave the Catholic hierarchy considerable influence on the Irish political process and on law-making in particular. The Republic of Ireland for much of the last century was a mono-cultural society in which the Church was the ultimate arbiter of morality on an assortment of social issues concerning sex and sexuality, including censorship, reproduction, contraception, abortion and sex outside the bonds of marriage. ${ }^{121}$ As Inglis notes, citing Lee, there was a "virtual equation of morality with

113. Arnold, above n 22, p 58.

114. Ibid, ch 4 .

115. Arnold, above n 22 .

116. Ibid, $\mathrm{p} 13$.

117. The Republic of Ireland Act 1948 established Ireland as a Republic. It ended the remaining constitutional role of the British monarchy by vesting in the President the power to exercise the executive authority of the state in its external relations.

118. Arnold, above $\mathrm{n} 22, \mathrm{p} 38$. See, generally, TP Coogan Eamon De Valera: The Man Who Was Ireland (London: HarperCollins, 1996).

119. Raftery and O'Sullivan, above $\mathrm{n} 22$, ch 5 .

120. Ibid, ch 6 .

121. See, especially, T Inglis Moral Monopoly: The Rise and Fall of the Catholic Church in Ireland (Dublin: University College Dublin Press, 2nd edn, 1998). See also É Walshe Sex, Nation and Dissent (Cork: Cork University Press, 1997). 
sexual immorality'122 and a related emphasis on the virtues of chastity, virginity, modesty, piety and sobriety which was reinforced in Irish homes, schools and communities, and directed towards women and children in particular. ${ }^{123}$ As a result, sex and sexuality became associated with the precarious undertones of silence, denial and secrecy which set the stage for the abuse of children and its subsequent cover-up. ${ }^{124}$ Such was the power of the Church and its teachings that the Victorian obsession with purity and the feelings of shame, embarrassment, prudery and guilt that came to be linked with sex were used as a part of a wider cultural process of patriarchal social control. ${ }^{125}$

Concurrently, it has been argued that the oppression of sexuality by both the Catholic Church and the Irish State can also be understood within the context of the struggle for national identity. ${ }^{126}$ The violation of sexual norms was regarded as particularly profane and as an attack on 'mother church' and 'mother Ireland' ${ }^{127}$ As Inglis has argued: 'It was because these struggles for symbolic and economic power took place in and through the Catholic Church that this particular institution developed a monopoly position in the fields of family life, health, education, and social welfare.' ${ }^{128}$ The issue of identity will be returned to below.

This moral hegemony of the Church in Ireland remained until late in the twentieth century when a period of rapid social change, the growth of education and the media, and an easing of censorship facilitated the acceptance of alternative discourses about sex, beginning in the 1960s. ${ }^{129}$ As a result, revelations about the institutional abuse of children in Ireland had profound implications for Irish society. The gulf between the rhetoric and behaviour of clerical abusers also helps to explain the opprobrious public reaction when allegations of such abuse emerge and the 'deep hurt' ${ }^{130}$ and spiritual damage ${ }^{131}$ expressed by the Catholic community in response to perceived betrayal by the Church. ${ }^{132}$

Thirdly, the influence of Catholic morality is arguably a pertinent reason why official recognition of child sexual abuse as a serious social problem did not come about until much later in comparison to more secular states. Although prohibitions

122. JJ Lee Ireland, 1912-1985: Politics and Society (Cambridge: Cambridge University Press, 1989) p 645.

123. $T$ Inglis 'Origins and legacies of Irish prudery: sexuality and social control in modern Ireland' (2005) 40 Éire-Ireland 9.

124. See MG Frawley-O'Dea Perversion of Power: Sexual Abuse in the Catholic Church (Nashville, TN: Vanderbilt University Press, 2007).

125. Inglis, above $\mathrm{n}$ 123. See also F Harrison The Dark Angel: Aspects of Victorian Sexuality (London: Sheldon Press, 1977).

126. See G Meaney Sex and Nation: Women in Irish Culture and Politics (San Francisco, CA: Attic Press, 1991).

127. CL Innes Women and Nation in Irish Literature and Society, 1890-1935 (Hemel Hempstead: Harvester Wheatsheaf, 1993) pp 26-42.

128. Inglis, above $\mathrm{n} 123$, at $23-24$.

129. Ibid, at 30. See, generally, L. Gibbons Transformations in Irish Culture (Cork: Cork University Press, 1996); Ferriter, above n 103.

130. PM Kline, R McMackin and E Lezotte 'The impact of the clergy sexual abuse scandal on parish communities' (2008) 17 Journal of Child Sexual Abuse 290.

131. SJ Rosetti 'The impact of child sexual abuse on attitudes toward God and the Catholic Church' (1995) 19 Child Abuse and Neglect 1469.

132. Note, however, that Church attendance actually rose in Ireland in the aftermath of the publication of the Ryan and Murphy reports in late 2009, which has been attributed to the recession. See 'Mass attendance in Ireland is up', The Irish Times, 11 November 2009. 
against incest are now almost universal, prior to the Punishment of Incest Act 1908 such cases were dealt with by the ecclesiastical courts, in both England and Ireland, as offences against morals and religion. ${ }^{133}$ Social recognition of child physical abuse first came about in the USA in the early $1960 \mathrm{~s},{ }^{134}$ followed by sexual abuse in the late 1970s. ${ }^{135}$ In Europe, in general, however, an awareness of child sexual abuse did not emerge until some years later. ${ }^{136}$ Catholic cultures such as France and Southern Germany were slow to recognise sexual abuse as a moral, legal and social problem, compared to Protestant or secularised cultures such as the USA, England, Canada, Sweden, Norway, the Netherlands and Northern Germany. ${ }^{137}$

Indeed, in 1931, the Irish Government commissioned an inquiry to review the Criminal Law Amendment Acts (1880-1855) pertaining to sexual crimes and to examine juvenile prostitution in the country. ${ }^{138}$ The report indicated a rise in sexual crimes in general, and against children in particular, and reported that less than 15 per cent of these cases were prosecuted due to the desire of parents to keep the abuse secret. These findings, however, were thought to be damaging to the standard of morality in the country and the report was suppressed by the State. ${ }^{139}$ This picture is also confirmed by an analysis of the Irish inquiries into intra-familial abuse in the 1990s. As outlined above, the failure of the authorities to intervene was attributed to an emphasis on maintaining the family unit as well as disbelief among practitioners about the existence of sexual abuse. ${ }^{140}$ It was only with the advent of the high-profile cases of institutional sexual abuse by priests in particular that the issue exploded into the public domain and could no longer be ignored.

Fourthly, the Church, in being given extensive autonomy in Irish society, became in itself 'a parallel form of government'. ${ }^{141}$ The Catholic Church is an institution with complex authoritarian power structures, a patriarchal style of governance, ${ }^{142}$ and its own system of principles and rules based on the naturalist codes of Canon law. ${ }^{143}$ The Ferns Inquiry, for example, confirms that the rules of canon law did provide for investigative procedures and the internal handling of suspected cases of abuse which were often not implemented. ${ }^{144}$ Moreover, the most recent Cloyne Report highlights how the Church did not implement its own protocols for dealing with allegations of abuse and also did its best to avoid any application of the laws

133. S Wolfram 'Eugenics and the Punishment of Incest Act 1908' (1983) Criminal Law Review 308.

134. H Kempe, FN Silverman, BF Steele, W Drogemueller and MK Silver 'The battered child syndrome' (1962) 181 Journal of the American Medical Association 17.

135. H Kempe 'Sexual abuse: another hidden pediatric problem' (1978) 62 Pediatrics 382.

136. C Bagley and K King Child Sexual Abuse: The Search for Healing (London: Routledge, 1990).

137. See JC Chesnais History of Violence in the West (Paris: University of Paris, 1981).

138. Irish Government Report of the Committee on the Criminal Law Amendment Acts (1880-5) and Juvenile Prostitution (1931) unpublished. ('The Carrigan Report').

139. Raftery and O'Sullivan, above n 22, p 257.

140. See McGuinness, above n 31; North Western Health Board, above n 32.

141. Arnold, above n 22, p 58.

142. M Keenan 'The institution and the individual' (2006) 57 The Furrow 3 at 6.

143. The revised version was promulgated in 1983 and applies to Roman Catholics of the Latin Rite. See Canon Law Society Code of Canon Law (1983). See also TP Doyle 'Canon law and the clergy sexual abuse crisis: the failure' in TG Plante (ed) Sin Against the Innocents: Sexual Abuse by Priests and the Role of the Catholic Church (London: Praeger, 2004).

144. Ferns Report, above n 15, pp 44-47. 
of the State by failing to report all complaints to the Gardaí and any complaints to the health authorities. ${ }^{145}$

In a very real sense, therefore, the investigation of allegations of sexual abuse by clergy fell between two stools in that neither the Church nor the State was prepared to take ownership of the problem. The inquiry reports underline the deficiencies in both canonical and secular law and failings by both ecclesiastical and civil authorities. The supposed claim to self-regulation by the Church, and the State's compliance in this, were used to evade the normative legal framework and the legal viability of prosecution. Although the authority for this deference was based on less than solid legal foundations, the cultural and political deference to canon law which emerged resulted in a de facto and, for decades, de jure impunity for abusers.

There is a considerable amount of intrigue and secrecy surrounding not only the workings of canon law, but also clerical culture, and the rituals of the Church and its inner sanctum. ${ }^{146}$ The Vatican, roman curia ${ }^{147}$ and papal bureaucracy are perceived as among the most enigmatic and secretive elements of the Roman Catholic tradition. ${ }^{148}$ The Vatican in particular is a particularly complex institution - a sovereign political state as well as an autocratic religious entity. ${ }^{149}$ This adds a further level of subterfuge to the institutional child abuse scandal, as a subject that is already poorly understood. ${ }^{150}$ As will be discussed further below, the Church has been anxious throughout to maintain its intense privacy and protect its closed and privileged world. The Ryan Report, for example, concluded that the 'desire to protect the reputation of the Congregation and institution was paramount' ${ }^{151}$ Similarly, the Murphy Report noted 'the obsessive concern with secrecy and the avoidance of scandal' to which the protection of children was subordinated. ${ }^{152}$ Indeed, it has also been argued that is these organisational facets of a bureaucratic Church 'governed by informal rules that value autonomy, secrecy and maintaining the status quo' that facilitate deviance. ${ }^{153}$

\section{(b) Discourses on denial and the preservation of identity}

There are two further interrelated theoretical explanations which I would suggest provide additional barriers to truth recovery in the aftermath of institutional child abuse in Ireland. One relates to the politics of denial whereby organisations refute or minimise their involvement in any previous wrongdoing; the other, the disparity between a nation's benevolent self-image and the legacy of an abusive past. In relation to the first of these elements, Anderson examines the creation of 'imagined communities' of nationality which are shaped by a complex interplay of factors, including,

145. Cloyne Report, above n 18, para 1.21 .

146. Keenan, above $n 142$.

147. The roman curia is the administrative structure of the Holy See and, together with the Pope, constitutes the central governing body of the Catholic Church.

148. For a detailed discussion, see TP Doyle, AWR Swipe and PJ Wall Sex, Priests and Secret Codes: The Catholic Church's 2000-year Paper Trail of Sexual Abuse (Santa Monica, CA: Volt Press, 2006).

149. Formicola, above n 100 , at 480 .

150. Doyle et al, above $\mathrm{n} 148, \mathrm{p} 5$.

151. Ryan Report, above n 16, vol. IV, para 6.20.

152. Murphy Report, above $n$ 17, paras $1.32,1.35$.

153. MD White and $K$ Terry 'Child sexual abuse in the Catholic Church: revisiting the rotten apples explanation' (2008) 35 Criminal Justice and Behaviour 658 at 665. 
inter alia, the territorialisation of religious faiths and the decline of antique kinship. ${ }^{154}$ The sense of the Irish State as a 'community' or 'fraternity' with 'deep, horizontal comradeship', ${ }^{155}$ bound by the ties of kinship and religion, can be traced to the roots of Irish nationalism in the twelfth century. ${ }^{156}$ The creation of Ireland as an independent sovereign state in the first half of the twentieth century was 'the gage and emblem' ${ }^{\text {'57 }}$ of nationhood. When Ireland joined the EU in the early 1970s this marked a change in status and identity from a small, independent, neutral nation to a progressive, modern one. As Anderson argues, however: 'All profound changes in consciousness, by their very nature, bring with them characteristic amnesias, [where identity] because it cannot be "remembered", must be narrated." 158

The notion of 'community' may also be invoked to establish a climate of fear and suppress dissent in relation to abuses of State power. ${ }^{159}$ As McEvoy has argued, drawing on the work of Douglas:

'[S]tates and state-like institutions are particularly prone to developing and re-producing their own rationality, their own reason for being [where] sameness [is] shaped by the shared thought, values, and information within the institutions. ${ }^{160}$

In general terms, a democratic state is 'politically self defined [sic] by values which would seem to exclude certain types of behaviour' and is therefore called upon to examine its own political identity in the face of systematic human rights violations. ${ }^{161}$ What makes the Irish situation unique, however, is the dual historical and sociological evolution of imagined political and religious communities, each with their own cultures and philosophies. Child physical and sexual abuse is abhorrent, and neither the Catholic Church nor the Irish State wanted to visualise itself in such terms. In order to make sense of its abusive past, these institutions had to employ rationalising mechanisms to render them 'legible'. ${ }^{162}$

The Irish State, in an attempt to verify the impossibility of transgression and police its own past, reclaimed its 'ancient title to sanctity and scholarship' 163 by adopting a number of neutralising discourses. ${ }^{164}$ Indeed, Raftery and O'Sullivan note that the industrial school system was 'bedevilled with myth' and cultural misconceptions that

154. Anderson, above $\mathrm{n} 25$.

155. Ibid.

156. See, generally, R. Kee The Green Flag: A History of Irish Nationalism (Harmondsworth: Penguin, 2000) pp 9-14. The republican conception of national identity, originating in the United Irishmen movement, was politically constituted and non-sectarian in nature (ibid, pp 54-62).

157. Anderson, above n 25, p 7.

158. Ibid, p 204.

159. HA Giroux 'Democracy and the politics of terrorism: community, fear and the suppression of dissent' (2002) 2 Cultural Studies 334.

160. McEvoy, above n 87, at 422. See also M. Douglas How Institutions Think (Syracuse, NY: Syracuse University Press, 1986).

161. Ní Aolaín and Campbell, above n 86, at 207.

162. McEvoy, above n 87, at 422 .

163. T O'Malley Sexual Offences: Law, Policy and Punishment (London: Round Hall/Sweet \& Maxwell, 1996) p 6.

164. See, generally, Sykes and Matza's neutralisation theory whereby those who commit deviant acts neutralise behavioural norms which would normally prohibit deviant behaviour. G Sykes and D Matza 'Techniques of neutralization: a theory of delinquency' (1957) 22 American 
were readily perpetuated by the State and the religious orders in an attempt to explain their past failures to intervene. ${ }^{165}$ Chief among these was the myth that children within the system were the object of Christian charity, whereas in reality, the system was established by law and funded by the State. Further, that these institutions were reformatories for those found guilty of criminal offences. In fact many children were institutionalised not for criminality, but simply because their families were poor and unable to care for them. A final myth is that the State in particular remained in the dark about these abuses until they eventually came to light in the last few years. While there may have been cultural unawareness of the scale of abuse, as noted above, both the Church and the State were made aware of the existence of institutional child abuse in various ways over the years. In this sense, the apology by the Irish State in May 1999 to victims of institutional abuse in Ireland and the setting up of the Ryan Commission soon thereafter was emblematic of a modern and progressive nation which was prepared to confront the past.

The ecclesiastical response to allegations of child sexual abuse can be framed in terms of the intersection of not only how Church authorities constructed or viewed perpetrators, but also how they saw themselves. In this respect, revelations about the commission of such heinous acts by members of religious orders 'breache[d] the boundaries of [their] identity', ${ }^{166}$ and by extension that of the Church, as wholesome, trustworthy and the epitome of Catholic morality. This inward struggle with public identity also helps to explain the tendency of the Church to distance itself from allegations of sexual abuse by failing in particular to admit the extent of its knowledge of abuse and by normalising and pathologising such cases as an aberrational rather than a systemic problem. A common response of Church authorities on receiving abuse complaints was to treat the problem as a moral or psychological one within the dominant discourses of religion or medicine.

In relation to the second component, Cohen suggests that there are typologies of denial, ${ }^{167}$ many of which can be related to the response of the Irish State and the Catholic Church to institutional child abuse. At the collective or organised level, 'social amnesia' becomes the mode by which an entire society separates itself from a disreputable past. ${ }^{168}$ This mode of denial may take place via organised attempts to cover up any records of past abuses ('the conscious cover-up') or 'revisionist histories' which suppress uncomfortable knowledge and dismiss the event as 'myth' ('the convenient forgetting' and 'the euphemistic renaming'). There is a standard rhetoric of official responses to allegations of previous human rights atrocities which is comprised of three sequential or more often simultaneous elements: 'literal' or outright denial; 'interpretive' denial where in partial acknowledgement, usually in response to evidence from journalists or victims, the facts are given an alternative meaning; or 'implicatory' denial or justification where the political or moral implications of the event are minimised or denied. ${ }^{169}$ While all of these contingencies of denial appear to varying degrees within Church and State responses to institutional child abuse in Ireland, a number of exemplars stand out.

Sociological Review 664. See also S Maruna and H Copes 'What we have learned in five decades of neutralization research (2005) 32 Crime and Justice: A Review of Research 221.

165. Raftery and O'Sullivan, above $\mathrm{n} 22$, ch 5 .

166. Keenan, above n 13, at 212.

167. Cohen, above n 24; Cohen, above n 72 .

168. Cohen, above n 72 , at $12-22$.

169. Ibid, at 15. 
The discourse of official denial by the Irish State went through a continuum of stages from the historic suppression of the Carrigan Report in the 1930s to the contemporary first public apology to victims following television documentaries on the subject in the 1990s. The State in particular displayed an extraordinary capacity for 'double-think' which allowed the abuse to continue. ${ }^{170}$ Public discourses about the industrial schools system during its lifetime were characterised by two contradictory attitudes: on the one hand, the system was not regarded as brutal at all, while on the other, its whole purpose was seen as being brutal - 'Troublesome children were a threat to public order, so any means were justifiable in their subjugation. ${ }^{171}$ This self-justification and the proclamation of serving higher goals are akin to Cohen's third element above, what he refers to as 'the crucial subtext' - 'what happened anyway was justified'. ${ }^{172}$ Such claims however, can also displace the need for accountability to the wider public and victims in particular. There is also evidence of appeal to 'historical relativity', 'to be judged not by the standards of today ... but the standards of the past' ${ }^{173}$ The essence of this defensive stance is that it is unfair to single out the religious orders or the State for blame since 'in the Ireland of the 1950s children everywhere were badly treated, and that this was the accepted norm'. ${ }^{174}$ By appealing to these 'subterranean values', ${ }^{175}$ which supposedly permeate throughout society, the State closes ranks around any law-breaking and 'the illegality creates a new dispensation, a new constitution that nullifies the old' ${ }^{176}$

The organisational culture of the Church itself also helps to create a double layer of subterfuge which facilitates denial and obfuscates the truth. The Catholic Church has maintained a policy of secrecy throughout and appears to drift between outright denial and part acknowledgement of abuses usually when confronted with overwhelming evidence of their existence. In this sense, theirs is variously a denial of both knowledge and responsibility. ${ }^{177}$ The key rhetorical device is the continued insistence by the Church that it had either no historical knowledge of clerical abuse at Vatican level or no such policy of mandatory internal handling of complaints. ${ }^{178}$ This, as noted above, has also been combined with a wider denial of institutional responsibility in seeking to isolate the problem to individual cases. As also noted above, the Church's historical denial and cover-up of allegations of institutional child abuse and their refusal to acknowledge victim's suffering has impaired its moral integrity and institutional legitimacy. ${ }^{179}$

A broader level of denial resonates through the practices of child care institutions themselves which also spills over into wider society. It has been argued, in this respect,

170. F O'Toole 'Our capacity for double-think allowed abuse to continue', The Irish Times, 2 June 1999.

171. Waters, above n 19.

172. Cohen, above $\mathrm{n} 72$, at 15 .

173. Ibid, at 46-47.

174. Raftery and O'Sullivan, above $\mathrm{n} 22$, p 14.

175. D Matza and G Sykes 'Juvenile delinquency and subterranean values' (1961) 26 American Sociological Review 712.

176. Waters, above n 19.

177. Cohen, above n 24, pp 78-95.

178. It has recently emerged, for example, that the Vatican warned Irish bishops not to report all suspected child abuse cases to police but instead sanctioned the internal handling of such cases within the confines of Canon law. See S Pogatchnik 'Vatican letter cited as cover-up, Associated Press, 19 January 2011.

179. McEvoy and Mallinder, above $n 23$. 
that child care institutions appear to be 'self-protective, secretive and closed by nature' and as such deflect attention away from deficiencies in policies or the signs of abuse. ${ }^{180}$ Moreover, if an organisation, such as the Church, is held in high regard by professionals, parents and wider society, children may have additional difficulties in uncovering the abuse and getting adults to believe them. ${ }^{181}$ The inquiries confirm that abusive practices were deeply embedded and maintained through institutions run by the Church through a conspiracy of silence, fear and coercion. The Murphy Report in particular denoted a 'culture of secrecy' surrounding sexual abuse. ${ }^{182}$ The Ryan Report also describes a 'culture of silence' ${ }^{183}$ and the fact that 'complaints were ignored, witnesses were punished, or pressure was brought to bear on the child and family to deny the complaint and/or to remain silent' ${ }^{184}$ Some victims remember nuns and brothers who showed them kindness, ${ }^{185}$ but who never dared speak out against their more violent colleagues, so that the system was reinforced by the group dynamic and allowed to continue. Indeed, over the lengthy period when institutional and institutionalised abuse was taking place in Ireland, civil society also failed to appreciate the possible risks to children, simply by virtue of social denial and a 'culture of disbelief' concerning clergy sexual abuse. ${ }^{186}$

\section{CONCLUDING THOUGHTS}

This analysis has argued that there have been a number of important variables which appear to have underpinned the historic suppression of truth in the specific context of the aftermath of institutional child abuse by the clergy in Ireland. Although some of these have been to the forefront of international transitional justice discourses more generally (the dominance of law, the monolithic power of the State and the deepseated resistance of elite bodies to institutional change), a number appear to emerge more uniquely from a study of the Irish situation. In particular, the fusion of religion, politics, morality and trust, underpinning the Church-State-Civil Society relationship, is the crux of dealing with the politics of the past. Ireland as society that has witnessed gross abuses of power by the State and the Church also provides a number of important lessons for contemporary transitional justice contexts more broadly as well as other jurisdictions, such as Northern Ireland and Australia, who are currently grappling with the issue of historical institutional child abuse.

In the main, transition in contemporary settled democracies would appear to be considerably more complex than paradigmatic transitions within societies emerging from political or civil conflict. ${ }^{187}$ Within Ireland, the historic and deeply enmeshed political relationship between Church and State to date has made the process of transition from past abuses inherently more problematic. The democratic nature of the

180. McAlinden, above n 33, p 353.

181. B Gallagher 'The extent and nature of known cases of institutional child sexual abuse' (2000) 30 British Journal of Social Work 795 at 810.

182. Murphy Report, above n 17, para 1.28 .

183. Ryan Report, above, n 16, vol IV, para 29.

184. Ibid, Executive Summary; see also vol III.

185. See, eg, Raftery and O'Sullivan, above n 22, p 33; see also Ryan Report, above n 16, vol III, ch 10 .

186. T O'Malley 'Responding to institutional abuse: the law and its limits' in T Flannery (ed) Responding to the Ryan Report (Dublin: Columba Press, 2009) p 100.

187. Ní Aolaín and Campbell, above n 86. 
State, and a State-like institution such as the Church, makes it more difficult for these authorities to acknowledge past failings and effect institutional change. In this respect, the themes of 'significant resistance to change', the 'limited acknowledgement of past failings' and sites of multiple, open-ended, incremental transition, which are highly pertinent to truth recovery, have recurred throughout this analysis. ${ }^{188}$ In such a context, I would argue that uncovering the record of past atrocities has a number of implications for transitional processes within settled democracies and for the State in particular in terms of how it may assert 'discontinuity between past and present' ${ }^{189}$ In essence, in the absence of a regime transition established in the aftermath of civil or political conflict, the State has a much more onerous task in signifying a break with the past.

First, at the level of semantics, it is axiomatic that 'truth' is necessary for 'truth recovery'. The Irish experience of dealing with the legacy of an abusive past indicates that the residual issue is full official and public disclosure of abuses of power - in particular the suppression of the truth by the Catholic Church, at the highest levels, for many decades as well as the extent of State involvement and its failure to intervene. It is the simple and often elusive pursuit of 'truth' itself, therefore, which would appear to be pivotal to the wider processes of social and personal healing. In order for victims and wider society to be able to countenance the sins of the past, an official public recognition of the injustice suffered by victims is paramount. As Huyse put it: 'It is the difference between knowledge and acknowledgement that counts. ${ }^{190}$ In such a context, truth emerges as being equally if not more important than accountability even where prosecution is viable and unlikely to endanger the stability of democracy. ${ }^{191}$ As will be argued further below, such acknowledgement and accountability can only come about not by the establishment of further public inquiries, but ultimately by recourse to fundamental political and legal reform.

Secondly, and following on from the previous point, this paper has underscored the inherent limitations of public inquiries as a key part of transitional justice processes and in constructing knowledge about the past. Public inquiries tend to be the primary tool used by the State when confronted with past abuses as a means of ascertaining the truth. There are, however, fundamental weaknesses in the public inquiry method in eliciting the truth in its broadest sense in terms of providing the fullest possible account of the causes, contexts and consequences of abuse. Public inquiries, in this respect, are often faced with an impossible task in uncovering a complete and objective truth in terms not only of the magnitude, longevity and historical nature of abuses, but which also takes cognisance of individual, institutional as well as societal dimensions. Moreover, this paper has highlighted the fact that the inherent limitations of public inquiries stem not only from their normative legal frameworks, but also, more importantly, their function within administrative and constitutional arrangements. In this sense, truth or investigatory commissions are not a panacea, but rather only one element of the synthesis of truth recovery, justice and coming to terms with the past. ${ }^{192}$ It is possible for public inquiries to advance truth recovery. ${ }^{193}$ I would argue, however,

188. Ibid, at 194.

189. Cohen, above $\mathrm{n} 72$, at 49 .

190. Huyse, above $n 77$, at 53 .

191. McEvoy and Mallinder, above $\mathrm{n} 23$.

192. Cohen, above $n$ 72. See also M Requa 'Truth, Transition and the Inquiries Act 2005' (2007) 4 European Human Rights Law Review 404.

193. Requa, above n 192. 
that while the inquiries had a clear symbolic role to play, they marked the commencement rather than the resolution of the process of truth recovery in practical terms. In this sense, the State needed the inquiries to establish its legitimacy, to be seen to be actively doing something, in the face of revelations about the systemic nature of historical institutional child abuse in its child care institutions. The limited reformative function of inquiries, however, as part of the process of transition and the inherently restrictive nature of their transformative potential in making recommendations, means that they lack the mandate to effect tangible change. Ultimately, therefore, it left to the ordinary legal process to address the wider social and systemic social problems which have underpinned past abuses as highlighted in the inquiry reports and their constituent recommendations.

Thirdly, a further issue to be noted in this context, as the Taoiseach's speech during the parliamentary debates on the Cloyne Report referenced at the beginning of the paper makes clear, is that this is a defining moment in Irish political and legal history, and in the nature of Church-State relations in Ireland, which offers a unique opportunity to make a permanent break with the past. The previous mixed and ambiguous relationship of Church and State in Ireland has taken a new turn and is no longer amorphous or undefined. Over the last few years, since the abuse scandals first began to emerge, the historically indulgent attitude of the State to the Catholic Church has been dramatically reversed. Signposts of this change are also exemplified in a number of recent - albeit embryonic - reform initiatives including the proposal to introduce mandatory reporting, and thus override religious freedom and the 'secrecy of the confessional', contained in the Criminal Justice (Withholding Information about Crimes against Children and the Vulnerable Bill) 2011; the moves towards a constitutional referendum on children's rights in the Republic; ${ }^{194}$ as well as the pressure brought to bear by the Minister for Education and Skills, in particular, for the Catholic religious orders to make their own funds available to provide compensation. ${ }^{195}$ The legal framework for the Church-State relationship has been sufficiently adaptable, therefore, to accommodate this different dynamic of relationship absent major legal and political reform. ${ }^{196}$ The rule of law itself, however, and in particular democratic reform processes, emerges as a very powerful and ultimately as a necessary tool in effecting transitional justice through structural reform and institutional change both at the level of symbolism as well as substance. In a consolidated democracy, therefore, there is 'no conceptual gulf between transitional justice and ordinary justice'. ${ }^{197}$ Rather, in this vein, I would go further and argue that transitional justice and normative legal processes are not separate entities, but become mutually dependent on each other; transitional justice becomes somewhat paradoxically dependent on 'ordinary justice' in order to maximise its potential and its chances of success in facilitating the moving on from the legacy of an abusive past. At the same time, facing the truth concerning past silence, and the failure to intervene in particular, through transitional and reformative processes becomes the bedrock of a properly embedded rule of law. ${ }^{198}$

194. The referendum is expected to take place in early 2012 and provisions inserted as the $28^{\text {th }}$ Amendment to the Constitution.

195. Ruairí Quinn TD, speaking on RTÉ Six-One News, 5 July 2011.

196. I am grateful to an anonymous reviewer for Legal Studies for alerting me to this point/issue.

197. EA Posner and A Vermeule 'Transitional justice as ordinary justice', (2004) 117 Harvard Law Review 761 at 763 , n 4.

198. K McEvoy 'What did the lawyers do during the war? Neutrality, conflict and the culture of quietism' (2011) 74 Modern Law Review 350. 


\section{Legal Studies}

Fourthly, the vernacular of change alone, however, may be insufficient to deliver the seismic institutional and structural changes which are integral to the process of transition. ${ }^{199}$ In this respect, the limitations of a legalistic State-centric framework in effecting regime and system change have been outlined above. ${ }^{200}$ It becomes vital, therefore, to embed 'bottom-up' corrective mechanisms into democratic reformative and transitional justice processes and to give victims, the community and non-State actors a stake in and ownership of such processes. ${ }^{201}$ To paraphrase Posner and Vermeule: 'Every transition seeks political reform, and the transition can be judged by the quality of the political [and legal] reforms achieved. ${ }^{202}$ In other words, in the task of knowledge construction about the past what counts ultimately is a pragmatic approach which acknowledges and engages with previous wrongdoing via comprehensive and revisionist legal and policy agendas. Others have argued that only through fundamental institutional reform can a more accountable and representative Church emerge. ${ }^{203}$ Equally, I would contend that such an approach on the part of the State would offer a more pragmatic, holistic and auspicious approach to truth recovery which signifies a clear attempt to confront the past and cement its identity as an advanced liberal democracy that has managed to move on from a legacy of abuse.

199. M O'Rawe 'Transitional policing arrangements in Northern Ireland: the can't and won't of change dialetic' (2003) 26 Fordham International Law Journal 1015.

200. McEvoy, above n 87.

201. McEvoy and McGregor, above $n 68$.

202. Posner and Vermeule, above n 197, at 768.

203. M Keenan Child Sexual Abuse and the Catholic Church: Gender, Power and Organizational Culture (Oxford: Oxford University Press, 2011). 